\title{
0.0. Sozinov - a prominent Ukrainian agrobiologist and organizer of domestic agricultural science
}

\author{
Verhunov V. \\ National Scientific Agricultural Library of the NAAS \\ 10 Heroiv Oborony Str., Kyiv, 03127, Ukraine \\ e-mail: dnsgb uaan@ukr.net \\ ORCID: 0000-0002- 5476-4845
}

Purpose. To enlight the life and creative path of a prominent scientist in the field of plant genetics and selection Academician O.O. Sozinov, to summarize his scientific initiatives, achievements in the development of agricultural research in Ukraine. Methods. General scientific — analysis, synthesis, classification; historical - problem-chronological, comparatively historical, retrospective, biographical. Results. The contribution of the scientist to the formation of leading sectoral scientific institutions and organizations - the Selection and Genetic Institute - NSC of Seed Science and Variety Research of NAAS, Institute of General Genetics named after M.I. Vavylov, VASGNIL, NAAS, and others. The role of O.O. Sozinov's scientific school in the development of the basics of plant biochemical and molecular genetics is shown. Conclusions. The scientific heritage of the scientist has been systematized in the following fields: genetics and selection, biology and morphology, anatomy and cytology of plants, agro phytocoenoses, agrobiotechnology, ecological problems of agriculture, seed production, problems of genomics.

Key words: plant growing, genetics, selection, agroecology, National Academy of Agrarian Sciences of Ukraine.

DOI: https://doi.org/10.31073/agrovisnyk202005-11

Socio-economic and cultural-educational revival of Ukraine requires comprehensive coverage of all stages of its historical development, first of all, it concerns the leading sector of the economy - agriculture. The experience of the developed countries of the world shows that without proper scientific support it is impossible to judge the dynamic progressive development of the agricultural sector, and most importantly, the food security of the country and its independence. Outlining further ways of effective functioning of academic branch science in Ukraine, it is important to study the historical experience of agricultural research development taking into account the personalized dimension of advanced scientific initiatives and strategies for its development.

Doctor of Agricultural Sciences, Professor, Academician of NAAS and NASU and 16 other academies of the world, First Vice-President of the All-Union Academy of Agricultural Sciences named after Lenin (VASGNIL) (1978-1982), Chairman of the Presidium of the Southern Department of VASGNIL - Deputy Chairman of the State Agrarian Industry of the USSR (1987-1990), the first President of the National Academy of Agrarian Sciences of Ukraine (1990-1996) Oleksiy Oleksiyovych Sozinov made a significant contribution in the formation of scientific support of agriculture in Ukraine in the second half of 20th - early 21st century. He laid the foundations for the development of cell biology, cytogenetics, grain quality genetics and the genetic basis of selection, immunogenetics, seed science, embryogenetics, molecular biology, and the use of mathematical methods in biology. The scientist is the author of fundamental research on genetics and selection of cultivated plants, a world expert on grain quality, the developer of conceptual provisions that are of fundamental importance for further study of the genetic basis of selection. Oleksiy Sozinov worked on the problems of genomics, agrosphere, biodiversity conservation and environment in the context of sustainable development, substantiation of the need to study the agrosphere of Ukraine as a single system that determines the quality of life of its population.

Some areas of activity and achievements of the scientist are covered in the previous publications and editions [1-6], but a comprehensive study of intellectual biography and scientific initiatives by O.O. Sozinov has not been held so far. Resolution № 325-IX of December 3rd, 2019 «On the celebration of memorable dates and anniversaries in 2020» (as amended), approved by the Verkhovna Rada of Ukraine on the occasion of the 90th anniversary of his birth, as well as the Resolution of the Presidium of NAAS № 02/04 of 19.02.2020 (Minutes № 2) encourage to pay tribute to the scientist for what he did in the name of the future, to rethink his outstanding contribution to the development of branch scientific thought again, to return to the assessment of his creative path.

The purpose of the research is a scientific-historical analysis of the life and scientific path of Academician O.O. Sozinov, generalization of his creative research on the development of the basics of genetics, selection, plant biotechnology and agroecology, coverage of his contribution to the development of agricultural research, popularization of the achievements of agricultural science in Ukraine. 
Research methods. The research is based on the principles of historical knowledge: objectivity, systematicity, continuity, complexity, multifactoriality. General scientific (analysis, synthesis, classification) and structural-functional methods are used. Stateful attention is paid to historical methods of research search (problem-chronological, comparative-historical, retrospective, biographical).

Results of the research. Oleksiy Sozinov was born on April 26th, 1930 (according to other sources 1929) in the village Yerzhovo, Rybnytsya district, USSR (now the Republic of Moldova) in the family of Oleksiy Abramovych, Head of the Adaptation Department of the Adzham Agricultural Research Station, and Oksana Kyrylivna, Yead of the Varietal Testing Department. In 1936, the Sozinov` family moved to Odessa. After graduating from the Institute of the Red Professorship in Moscow, father worked at the Odessa Agricultural Institute as the Head of the Department of Economics, and mother headed the staff of the local state varietal department.

In 1941, with the beginning of the Soviet-German war, he remained in the occupied territories. His father was a battalion commissar, who died heroically in the battles near Nikopol in 1941. In October 1943, O.O. Sozinov ended up to a German concentration camp in the village of Koblevo, where he and a group of boys and girls were being prepared for departure to Germany. However, in the village. Sychavka he managed to escape and return to Odessa. In the spring of 1944 he began his career first as a worker, and then as a trailer and machine operator in the elite farm "Dachne" in Odessa region. After graduating from the evening school № 6 for working youth, where children whose parents died at the front studied, he studied for a year at the Odessa Institute of Communications and was always well versed in technique and was perhaps the first in the Ukrainian Academy of Agrarian Sciences (UAAS) who used a personal computer). In 1949 he entered the Selection Faculty of the Odessa Agricultural Institute, graduating with honors in 1954. During his studies he was elected comsorg of the faculty and from the third year received a Stalin scholarship. Oleksiy Oleksiyovych worked as an agronomist at the Voznesenskaya Rice Variety Section of the Mykolayiv Region, and in 1955 he entered the graduate school of the All-Union Breeding and Genetic Institute. In 1958 he completed an internship at the World Plant Breeding Center in Sfalefi and other scientific institutions in Sweden. In 1959 he defended his dissertation for the obtain degree of Candidate of Agricultural Sciences at the Odessa Agricultural Institute: "Brewing barley in the south of Ukraine" under the scientific guidance of the Candidate of Agricultural Sciences, winner of the Stalin Prize, future VASGNIL Academician P.F. Garkavy, and his doctoral dissertation "Quality of wheat grain in the south of Ukraine and ways to improve it" in 1970 at the Ukrainian Research Institute of Plant Breeding, Selection and Genetics named after V.Ya. Yuriev [2].

In 1958 - 1961 in this institute O.O. Sozinov works as a Junior, Senior Researcher in the Laboratory of Wheat Breeding under the leadership of VASGNIL Academician, winner of the Lenin Prize F.G. Kyrychenko. From 1961 to 1966 - Head of the Laboratory of Grain Quality, in 1966-1971 - Deputy Director for Scientific Work and Head of the Department of Grain Technology; 1971-1978 - Director of the All-Union Breeding and Genetics Institute (Odessa) (now the Breeding and Genetics Institute - NSC for Seed Science and Variety Studies of NAAS). On the basis of the institute he initiated new areas of research: cell biology, cytogenetics, grain quality genetics and genetic bases of selection, immunogenetics, seed science, embryogenetics, molecular biology, the use of mathematical methods in biology. He created an international exchange gene pool, which was annually visited by breeders from around the world.

In 1978-1982, O.O. Sozinov - First Vice-President of VASGNIL, and from 1981 to 1987 - Director of the Institute of General Genetics named after M.I. Vavylov of the USSR Academy of Sciences (Moscow) and VicePresident of the All-Union Society of Geneticists and Breeders named after M.I. Vavylov. In 1987-1990, O.O. Sozinov headed the Presidium of the Southern Department of VASGNIL (Kyiv), and was also appointed Deputy Chairman of the State Agrarian Industry of the Ukrainian SSR. In 1987-1992, Oleksiy Oleksiyovych was a part-time Vice-President of VASGNIL, head of the Department of Applied Genetics and Biotechnology of the Southern Department of VASGNIL and the USSR Academy of Sciences. In 1973 he was elected a Corresponding Member, in 1978 - a full member (Academician) of VASGNIL and the USSR Academy of Sciences (Department of General Biology, specialty «Genetics») [3, 4].

Since 1988 he was active in the creation of the Ukrainian Academy of Agrarian Sciences. In 1990, the members of general meeting of the newly established Academy elected O.O. Sozinov a full member (Academician) (Department of Plant Breeding and Breeding) and its first President. Thanks to his efforts, UAAS quickly became a recognized center of agricultural science in Ukraine and abroad.

In 1992, on the initiative of the scientist, the Institute of Agroecology and Biotechnology of UAAS (now the Institute of Agroecology and Environment Management of NAAS) began to function, which became the main scientific and methodological center for comprehensive solutions to the transition of agriculture to sustainable development. Scientists of the institute have developed methods of rational environment management, improving the quality of products, preserving agricultural landscapes and creating optimal conditions for normal life of the rural population. O.O. Sozinov took care of the training of ecological specialists capable of forming a new agro-sphere in Ukraine. On his initiative in 1994 the Department of Agroecology and Biotechnology was established at the National Agrarian University (now the National University of Life and Environmental Sciences of Ukraine), which he headed for two years [1]. 
Since 2000, O.O. Sozinov - head of the Institute of Agroecology and Biotechnology UAAS, since 2002 Laboratory of Molecular Plant Genetics of the Institute of Food Biotechnology and Genomics NASU, Chief Researcher of the Institute of Plant Protection NAAS, Chairman of the NASU Commission on National Heritage of Ukraine. At the Institute of Plant Protection, NAAS has established an informal group to continue working on the problems of the agro-sphere or, more precisely, the mega-agroecosystem of Ukraine, which occupies almost $70 \%$ of its territory and affects the living conditions of the entire population. Since 1987 he was a member, and in recent years - an adviser of the Presidium of NASU.

For a long time O.O. Sozinov was a member of the committees for awarding the State Prizes of the USSR, the State Prizes of Ukraine in the field of science and technique, as well as the Presidium of the Higher Attestation Commission of Ukraine. He was twice elected President of the Ukrainian Society of Geneticists and Breeders named after M.I. Vavylov. He was a member of the Commission on Agrarian and Land Reform under the President of Ukraine, the Commission for the Development of the National Program for the Development of Agricultural Production for 1995-2005, the State Commission for Reorganization in Science, the National Commission for Bioethics, a full member (Academician) of the Russian Academy Agricultural Sciences (1992), the Academies of Agrarian Sciences of Belarus and Georgia, the Academy of Sciences of the Republic of Kazakhstan, the Academy of Sciences of the GDR (1978). He is an Honorary Professor of the Bulgarian Academy of Sciences. He was recognized as the Man of the Year (1997) and the Man of the Third Millennium (USA), the initiator and head of the International Center for Plant Genetics and Breeding of the Council for Mutual Economic Assistance (CMEA) [2].

Oleksiy Oleksiyovych Sozinov passed away on August 4th, 2018, buried in Kyiv. The scientific heritage of the scientist has not lost its practical significance at the present stage of development of agricultural science. Academician O.O. Sozinov is the author of more than 600 scientific works on genetics and selection of cultivated plants, including 8 monographs. After studying the features of genetic control of the biosynthesis of spare proteins of cereals, he first established the nature of the heredity of electrophoretic components of these proteins.

Based on genetic analysis of extensive experimental material, he developed the principle of using allelic variants of clusters of related genes as genetic markers. Analysis with these markers allowed to establish patterns of formation of stability of gene associations that determine the adaptation of genotypes to certain living conditions, as well as to identify the connection of allelic variants of blocks of spare protein components with the level of expression of economically valuable traits. These studies became the basis for the development of new approaches to the purposeful production of source material and selection of genotypes in the selection process, as well as in the study of the evolution of cereals. O.O. Sozinov formulated the hypothesis of interlocus associations, in particular for the spare proteins of wheat, which was included in the World Fund of General Genetics.

The developments of labeling with molecular genetic markers of different varieties is a fundamental point in modern varietal testing. Oleksiy Oleksiyovych investigated the peculiarities of the formation of coadaptive gene associations in the genomes of cultivated and wild cereals. The genetic classification of prolamins developed by scientists has gained international recognition, and the method of identifying genotypes of varieties and forms of cultivated plants by loci of spare proteins is an important aspect of modern seed production and varietal testing. In recent years, he actively worked on the problems of genomics, agrosphere of the 21th century, preservation of biodiversity and environment in the context of sustainable development, justification of the need to study the agrosphere of Ukraine as a single system that determines the quality of life of its population [1].

Oleksiy Oleksiyovych Sozinov is the author and co-author of 18 varieties of agricultural crops. He received 19 copyright certificates and patents. Under his scientific guidance, 45 candidates and 9 doctors of science were trained, who actually began research on the polymorphism of proteins and plant DNA. Among his learners are talented scientists: E.V. Ananiev, Yu.O. Asika, M. Bito, O.K. Haponenko, Г.B. Glazko, Ts.O. Egorov, G.V. Zayakina, M.M. Illichevsky, O.L. Kensior, V.G. Kozlov, E.V. Metakovsky, O.Yu. Novoselskaya, M.G.Parfentiev, V.M. Panin, O.S. Rustanbekov, A. Semikhatsky, O.P. Sydorenko, T.O.Sobko, A.I. Stakanova, G.A. Uzikova and others.

O.O. Sozinov - editor (1980-2001), and since 2001 - Deputy Editor-in-Chief of the international journal "Cytology and Genetics", editor of the collection of scientific papers "Agroecology and Biotechnology", member of the editorial boards of many domestic and foreign journals on genetics, breeding, biotechnology, general crop production, seed production, including "Bulletin of Agrarian Science", "Agricultural Science and Practice", "Reports of the NAS of Ukraine", "Genetics" (Russia), "Agrarian Science" (Russia), "Science and Life" (Russia), "Bulletin of NAU", "Selection and Seed Production", "Genetic Resources", "Agricultural Science and Education", "Biotechnology", "Biologisches Zentralbatt" (Germany). He is member of the International Society of Grain Chemistry, the European Society of Breeders, the American Association of Grain Chemistry, the Canadian Society of Geneticists, the Ukrainian International Committee on Science and Culture, the Ukrainian Society of Geneticists and Breeders named after M.I. Vavylov [2]. 
O.O. Sozinov was awarded the Orders of Lenin (1973), the October Revolution (1977), the Red Labor Banner (1971), "For Merit" III degree (2000), Diplomas of the Verkhovna Rada and the Cabinet of Ministers of Ukraine, NAS of Ukraine, UAAS, many medals, diplomas of ENEA USSR and Ukraine and other departmental awards. He was awarded the title of "Honored Worker of Science and Technique of Ukraine" (1990), he is a laureate of the State Prize of the Russian Federation in the field of science and technique (1995), the State Prize of Ukraine in the field of science and technique (1989). He was elected a Deputy of the Supreme Soviet of the USSR (1988-1991) [6].

\section{Conclusions}

Academician 0.O. Sozinov is a talented organizer of domestic agricultural research, who has made a lot of efforts to establish leading industry research institutions and organizations - the Breeding and Genetic Institute - NSC Seed Science and Variety Research of NAAS, the Institute of General Genetics named after M.I.Vavylov, VASGNIL and its Southern Department, NAAS, Institute of Agroecology and Environmental Management of NAAS, Institute of Food Biotechnology and Genomics of NASU. He contributed to the professionalization of the agricultural sector as the initiator of the organization of the Department of Agroecology and Biotechnology of National University of Life and Environmental Sciences of Ukraine. He founded a well-known scientific school in Ukraine and abroad on biochemical and molecular plant genetics. The main directions of scientific research of the scientist: genetics and selection, biology and morphology, anatomy and cytology of plants, seed production, agrophytocenoses, agrobiotechnology, ecological problems of agriculture and others. He made efforts to promote the achievements of agricultural science as an editor of the international journal "Cytology and Genetics", a collection of scientific papers "Agroecology and Biotechnology", a member of the editorial boards of many domestic and foreign journals on genetics, breeding, biotechnology, general crop production, seed production.

\section{References}

1. Verhunov, V. A. (2010). 80-richchya akademika NAN Ukrayiny O. O. Sozinova [80th anniversary of Academician of the NAS of Ukraine O. O. Sozinov]. Bulletin of NAS of Ukraine, 4, 65-66. [In Ukrainian].

2. Pyrozhkov, S. I., \& Verhunov, V. A. (2018). Pershyi prezydent Akademiyi agrarnyh nauk nezalezhnoyi Ukrayiny (pamyati akademika NAN Ukrayiny O. O. Sozinova) [The first president of the Academy of Agrarian Sciences of independent Ukraine (in memory of Academician of the NAS of Ukraine O. O.Sozinov)]. Bulletin of NAS of Ukraine, 9(19), 83-87. [In Ukrainian].

3. Borovskih, I. V. (1980). Sozinov Aleksei Alekseevich (materialy k biografii dejatelej s. -h. nauki) [Sozinov Aleksei Alekseevich (materials for the biography of figures of agricultural science)]. Moscow. [In Russian].

4. Sozinov Aleksej Alekseevich. Biologi: biogr. cpr. (1984). [Sozinov Alexey Alekseevich. Biologists: biographical guide]. Kiev: Scientific thought. (pp. 583-584). [In Russian].

5. Sozinov Oleksii Oleksijovych [Sozinov Oleksiy Oleksiyovych]. (1983). Ukrayins'ka radyanska encyklopediya [Ukrainian Soviet Encyclopedia]. 2nd ed. Kyiv. (Vol. 10, p. 292). [In Ukrainian].

6. Vergunov, V. A., Derlemenko, T. F., Anikina, O. P., Kyrylenko, L. A., Tovmachenko, V. M., \& Sokolov, V. Yu. (Verhunov, V. A. (Ed.)) (2010). Sozinov Oleksii Oleksijovych: biobibl. pokazhch. nauk. pr. za $1954-$ 2009 roky. Do 80-richchya vid dnya narodzhennya [Sozinov Oleksiy Oleksiyovych: biobibl. index of sciences. papers for 1954 - 2009. To the 80th anniversary of his birth]. 2nd ed. Kyiv: Agrarian science. [In Ukrainian]. 